\title{
EFFECTIVENESS OF CORRECTIVE WORK POSTURE IN ALLEVIATING MUSCULOSKELETAL DISORDER SYMPTOMS AMONG SALESWOMEN IN THE DEPARTMENT STORE
}

\author{
Nailatun Nadrah'), Gerry Silaban'), Taufik Ashar²) \\ 1)Department of Occupational Health and Safety, Faculty of Public Health, \\ Universitas Sumatera \\ 2)Department of Environmental Health, Faculty of Public Health, \\ Universitas Sumatera
}

\begin{abstract}
Background: Musculoskeletal complaints often occur in saleswomen who do awkward standing during work. Repair of standing position can reduce the risk of musculoskeletal pain. This study aimed to determine the effectiveness of corrective work posture on alleviating musculoskeletal disorder (MSD) symptoms among saleswomen in the department store.

Subjects and Method: This was a quasi experiment before and after with no control design conducted in Rantauprapat department store, North Sumatera. A sample of 30 saleswomen from the department store was selected for this study. The dependent variable was MSD scores as measured by Nordic Body Map (NBM). The independent variables were corrective work posture. The data before and after corrective work posture were compared and tested by Wilcoxon test.

Results: MSD scores 1, 2, and 3 days after corrective work posture were lower than before corrective work posture, and all of them were statistically significant.

Conclusions: Corrective work posture is effective to alleviate MSD symptoms among saleswomen.
\end{abstract}

Keywords: musculoskeletal disorders, work posture correction, Nordic Body Map

\section{Correspondence:}

Nailatun Nadrah. Department of Occupational Health and Safety, Faculty of Public Health, Universitas Sumatera, Medan, North Sumatera.

Email: nailatunnadrah@gmail.com. Mobile: +6281360661677.

The 4th International Conference on Public Health Best Western Premier Hotel, Solo, Indonesia, August 29-30, 2018 | 298 https://doi.org/10.26911/theicph.2018.05.12 